\title{
Compare the effect of amniotomy and oxytocin infusion in duration of labour
}

\author{
Katta Jyothi, Senadhipathi Shakunthala*
}

Department of Obstetrics and Gynecology, Government Medical College, Nalgonda, Telangana, India

Received: 19 May 2019

Accepted: 09 July 2019

\section{*Correspondence:}

Dr. Senadhipathi Shakunthala,

E-mail: drsujathapasula@gmail.com

Copyright: () the author(s), publisher and licensee Medip Academy. This is an open-access article distributed under the terms of the Creative Commons Attribution Non-Commercial License, which permits unrestricted non-commercial use, distribution, and reproduction in any medium, provided the original work is properly cited.

\begin{abstract}
Background: Labour is a unique experience in a women's life, it is a physiological but painful event. It is a dynamic and continuous process which cumulates in the birth of a healthy baby followed by expulsion of the placenta and the membranes. The objective of this study was to determine the effectiveness of amniotomy and oxytocin in terms of duration of labour, mode of delivery and maternal and fetal outcome.

Methods: A non-randomized comparative study of accelerating effect of oxytocin and amniotomy has been studied, in the age group of 19-30 years, who are admitted in obstetric ward 200 primigravidae were studied out of which 100 belongs to control group and 100 study group.

Results: In the study series 93 cases had labour lasting less than 4 hours when compared to only. The mean total duration of labour is reduced in study group with a difference of 204 minutes. Quantity and duration of blood loss is significantly less in study group when compared to control group. There was no significant difference in terms of mode of delivery, maternal and foetal outcome between the two groups.

Conclusions: Oxytocin infusion combined with amniotomy is safe and effective in accelerating the first and second stage of labour in apparently normal cases. No statistically significant adverse effects were noted with oxytocin infusion and amniotomy.
\end{abstract}

Keywords: Amniotomy, Duration of blood loss, Oxytocin infusion

\section{INTRODUCTION}

Labour is a unique experience in a women's life, it is a physiological but painful event. The agony a woman suffers is beyond description. It is a dynamic and continuous process which cumulates in the birth of a healthy baby followed by expulsion of the placenta and the membranes. Labour is characterized by "the presence of uterine contractions of sufficient frequency, duration, and intensity to cause demonstrable effacement and dilation of the cervix and progressive descent of fetus through the birth canal". Labour may be prolonged either due to ineffective uterine contractions or failure of the cervix to dilate. If it is prolonged and tedious it may produce a picture of mental anguish and physical morbidity to the mother. For the newborn child, a prolonged labour will pose danger to its survival and subsequent neurological development. ${ }^{1}$ Our responsibility as obstetrician has become critical in providing a health mother with an undamaged healthy child. Hence both the obstetrician and the women in labour would like to accomplish the delivery in the shortest possible time without compromise on the maternal and fetal safety. Along with amniotomy and early administration of oxytocin are used to hasten the labour. ${ }^{2}$

Concepts of acceleration of labour represent a complete break against the traditional attitude of watchful 
expectancy. It reduced the complications related to prolonged labour.

Prolonged labour is an important cause of maternal morbidity and contributes significantly to the half a million women who die annually as a result to child birth. Dystocia in women accounts for approximately one-half of all primary Caesarean sections.

Management of labour principles to shorten labour and achieve efficient uterine contractions to affect spontaneous delivery in primigravida patients. Active management of labour protocol consists of an accurate diagnosis of labour. Early amniotomy, frequent vaginal examinations, high dose oxytocin augmentation for slow labour progress (cervical dilatation less than $1 \mathrm{~cm} / \mathrm{hour}$ ), and continuous professional social support. ${ }^{3}$

Oxytocin is a polypeptide with amino acid residues, synthesized in the neural cell bodies of hypothalamic nuclei and transported to posterior pituitary gland Oxytocin increases the force and frequency of uterine contractions. Increase in contractility is due to heightened electrical activity of the myometrial cell membranes. The mechanism by which amniotomy speed up labour remains unclear. It is thought that when the membranes are ruptured, the production and release of prostaglandins and oxytocin increases, resulting in stronger contractions and quicker cervical dilatation. ${ }^{10}$

The objective of this study was to compare the effect of amniotomy and oxytocin infusion with the control group on the duration of $1^{\text {st }}$ and $2^{\text {nd }}$ stages of labour.

\section{METHODS}

Prospective study done in Department of Gynaecology and Obstetrics in 200 term pregnancy primigravida women for a period of 2 years with consent obtained from patients.

\section{Inclusion criteria}

- Term primigravidae

- Vertex presentation,

- Who has set into spontaneous labour

- Have 3-4 cm of cervical dilatation.

\section{Exclusion criteria}

- Multi gravidae

- Multiple gestation

- Malpresentation

- Cephalo pelvic disproportion

- Any known medical and obstetric complications and age below 18 years and above 32 years.

The Outcome of duration of $1^{\text {st }}$ and $2^{\text {nd }}$ stages of labour, mode of delivery, $3^{\text {rd }}$ stage blood, maternal outcome, fetal outcome. After taking detailed history and general examination, height of the funds, lie, presentation and frequency, intensity and duration of contractions were recorded by abdominal examination. Foetal heart sounds were checked for rate and regularity. Cardiotocography was done.

A preliminary sterile vaginal examination and pelvic assessment was performed to see the condition, effacement and dilatation of cervix, and to confirm that membranes were intact.

Women confirmed to be in active phase of labour when having cervix dilated at least 3-4 cm were enrolled for the study. After obtaining the informed consent, subjects were alternatively chosen as control group and study group.

Control group: $(\mathrm{n}=100)$

Patients were left for progress of labour with intact membranes and no oxytocin augmentation.

Study group: $(\mathrm{n}=100)$

Amniotomy was done at the onset of active labour (at 3-4 $\mathrm{cm}$ dilatation with fully effaced cervix) and 5 units oxytocin in $500 \mathrm{ml}$ of RL was started simultaneously at the rate of $5 \mathrm{mil} / \mathrm{min}$ units/min ( $8 \mathrm{drops} / \mathrm{min})$ and titrated half an hourly till adequate contractions achieved (3-4 contractions, lasting for 40-50 seconds in 10 minutes).

The membranes were ruptured by using Kocker's forceps in a controlled manner under aseptic measures with prophylactic antibiotics cover. The liquor was allowed to drain, while keeping two fingers in vagina making sure that the fluid drained slowly thus avoiding cord prolapsed and placental abruption. Colour of liquor was noted, whether colourless meconium or blood stained. If the colour of liquor was green or blood stained, patients were excluded from the study.

\section{Monitoring during the first stage of labour include}

- $\quad 4^{\text {th }}$ hourly temperature

- Hourly pulse and blood pressure

- Half-hourly documentation of frequency of contractions

- Frequency of emptying the bladder

- Vaginal examination offered every 2 hours for study group and every 4 hours for control group

- Intermittent electronic monitoring of the fetal heart after a contraction for at least 1 minute, every 15 minutes.

\section{Monitoring during the second stage of labour}

- Hourly blood pressure and pulse

- Continued 4 hourly temperature 
- Vaginal examination offered hourly in the second stage

- Documentation of the frequency of contractions every 10 minutes

- Frequency of emptying the bladder.

Assessment of progress by observing maternal behaviour, effectiveness of pulsing and fetal wellbeing. Intermittent electronic monitoring of the fetal heart after a contraction for at least 1 minute, every 5 minutes. Partogram was maintained for both the groups to see the progress of labour. Continuous CTG monitoring was carried out in suspected cases. In abnormal CTG cases emergency caesarean section was performed, while normal CTG cases monitoring of labour was continued. Fetal distress or non-reassuring fetal heart rate was defined as the presence of repeated late or severe variable decelerations loss of beat to beat variability not related to analgesia administration or persistent tachycardia over 160 beats/minute.

\section{Parameters taken immediately after delivery}

Baby assessed for Apgar score, $3^{\text {rd }}$ stage blood loss assessed by weighing the mops before and after soakage, mother general physical condition. Injection Methergin $0.2 \mathrm{ml}$ i.m. given for both groups. Oxytocin drip continued for 2-4 hours after delivery for study group.

\section{Observations during puerperium}

*The mother observed during puerperium for temperature, pulse rate, blood pressure, uterine involution, lochia, and successful voiding of the woman's bladder.

*The new born for NICU admissions.

\section{RESULTS}

Table 1: Demographic distribution of both the groups.

\begin{tabular}{|llll|}
\hline $\begin{array}{l}\text { Age in } \\
\text { years }\end{array}$ & $\begin{array}{l}\text { Control group } \\
\mathbf{N}=100\end{array}$ & $\begin{array}{l}\text { Study group } \\
\mathbf{N}=100\end{array}$ & $\begin{array}{l}\mathrm{P} \text { - } \\
\text { Value }\end{array}$ \\
\hline $19-21$ & 71 & 60 & $>0.05$ \\
\hline $22-24$ & 20 & 30 & $>0.05$ \\
\hline $25-27$ & 8 & 9 & $>0.05$ \\
\hline $28-30$ & 1 & 1 & $>0.05$ \\
\hline Duration of labour in hours & & \\
\hline $0-4$ & $32(33.3)$ & $93(94.8)$ & .001 \\
\hline $5-8$ & $43(44.7)$ & $4(4.1)$ & .001 \\
\hline $9-12$ & $21(21.8)$ & $1(1.0)$ & .001 \\
\hline
\end{tabular}

Total numbers of cases included in the study were 200 out of which 100 cases are taken as study group and 100 cases as control group.

Most of the people are in 19-21 years in both study and control group. In the study series $93 \%$ had labour lasting less than 4 hours when compared to only $32 \%$ cases in control series. In control group 4 cases and in study group 2 cases underwent caesarean section.

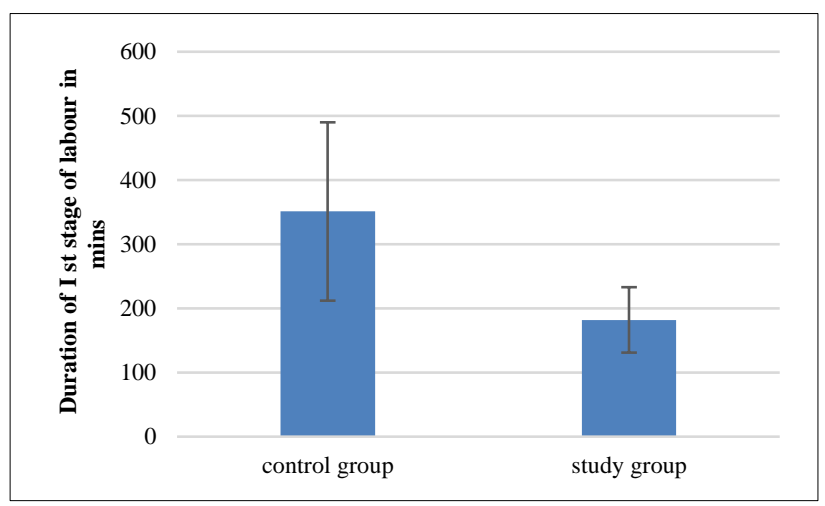

Figure 1: Comparison of mean duration of first stage of labour in both the groups.

The mean duration of $1^{\text {st }}$ stage of labour in control group is $351.4 \pm 139.72$ minutes when compared to study group which is $182 \pm 51.54$ minutes which is significant ( $p$ value->0.01).

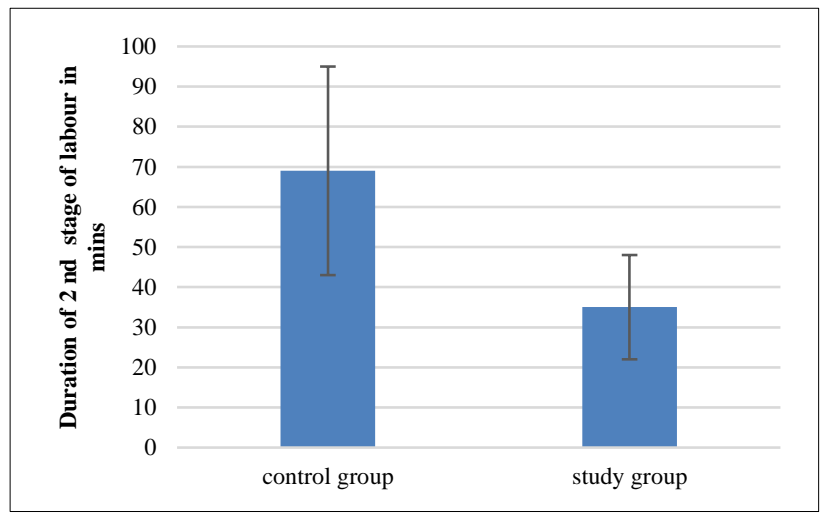

Figure 2: Comparison of mean duration of second stage of labour in both the groups.

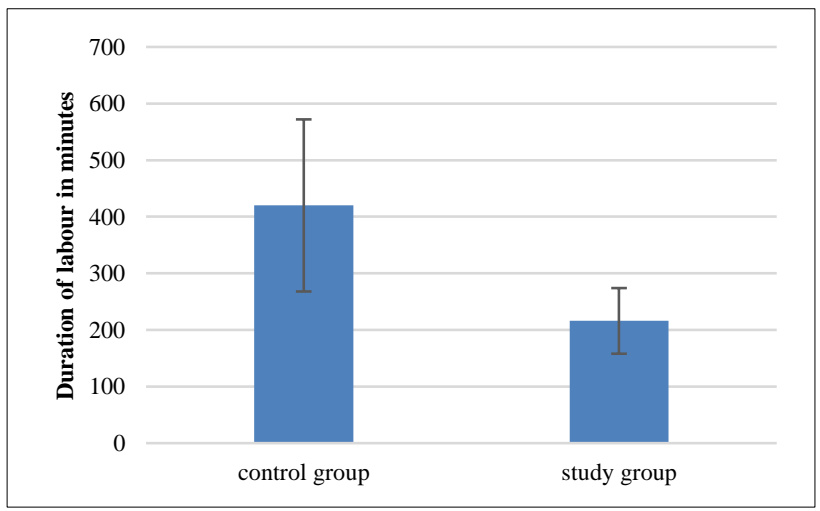

Figure3: Comparison of the mean total duration of labour in both the groups.

The mean duration of $2^{\text {nd }}$ stage of labour in the study group is $34.95 \pm 12.98$ minutes when compared to control 
group which is $68.8 \pm 26.14$ minutes which is significant (p-value->0.01).

The mean total duration of labour in study group is $420 \pm 152.78$ minutes when compared to the control group which is $216.75 \pm 58.35$ minutes which is significant (pvalue->0.01).

Table 2: Comparison of mode of delivery in both the groups.

\begin{tabular}{|llll|}
\hline Mode of delivery & $\begin{array}{l}\text { Control } \\
\text { group } \\
n=100\end{array}$ & $\begin{array}{l}\text { Study } \\
\text { group } \\
\text { n=100 }\end{array}$ & $\begin{array}{l}\text { P- } \\
\text { value }\end{array}$ \\
\hline Vaginal delivery & 78 & 88 & .111 \\
\hline Instrumental delivery & 18 & 10 & .111 \\
\hline Caesarean delivery & 4 & 2 & .111 \\
\hline
\end{tabular}

In the study group $88 \%$ had normal vaginal delivery whereas in the control group only $78 \%$. Instrumental delivery in the present series $18 \%$ in the control group and $10 \%$ in the study group. The introduction of a policy of active management of labour has reduced to a certain extent the incidence of instrumental delivery. Since first stage is shortened by syntocinon drip, patients do not require much assistance in the $2^{\text {nd }}$ stage of labour. Effective uterine contractions and good progress is maintained throughout labour. Caesarean section rate is more in control group.

Table 3: Comparison of mean quantity and duration of blood loss in 3rd stage in both the groups.

\begin{tabular}{|llll|}
\hline Parameter & $\begin{array}{l}\text { Control group } \\
\text { Mean } \pm \text { SD }\end{array}$ & $\begin{array}{l}\text { Study group } \\
\text { Mean } \pm \text { SD }\end{array}$ & $\begin{array}{l}\text { P- } \\
\text { Value }\end{array}$ \\
\hline $\begin{array}{l}\text { Amount of } \\
\text { blood loss }\end{array}$ & $211.6 \pm 79.52$ & $143.6 \pm 52.2$ & .001 \\
\hline $\begin{array}{l}\text { Duration of } \\
\text { blood loss }\end{array}$ & $7.6 \pm 2.83$ & $4.6 \pm 1.68$ & .001 \\
\hline
\end{tabular}

Amount and duration of blood loss is significantly less in study group when compared to control group.

Table 4: Comparison of the APGAR score at 5 min in both the groups.

\begin{tabular}{|llll|}
\hline $\begin{array}{l}\text { Apgar } \\
\text { score }\end{array}$ & $\begin{array}{l}\text { Control group } \\
\mathbf{N}=100\end{array}$ & $\begin{array}{l}\text { Study group } \\
\mathbf{N}=100\end{array}$ & $\begin{array}{l}\text { P- } \\
\text { Value }\end{array}$ \\
\hline$\geq 8$ & 92 & 96 & .136 \\
\hline$\leq 7$ & 8 & 4 & .136 \\
\hline
\end{tabular}

*In control group 8 babies had APGAR score $\leq 7$ compared to only 4 babies in study group.

In the control group 3\% mothers had puerperal morbidity. In the control group $10 \%$ babies had NICU admission whereas in the study group only $6 \%$ babies. In the control group $8 \%$ babies had fetal distress whereas in the study group only $4 \%$ babies. There were no still births or neonatal deaths in the present series either in control or study group.

Table 5: Comparison of maternal and fetal complications in both the groups.

\begin{tabular}{|llll|}
\hline & $\begin{array}{l}\text { Control } \\
\text { group } \\
n=100\end{array}$ & $\begin{array}{l}\text { Study } \\
\text { group } \\
n=100\end{array}$ & P- Value \\
\hline Puerperal morbidity & 3 & 0 & .385 \\
\hline Fetal distress & 8 & 4 & .326 \\
\hline NICU admissions & 10 & 6 & .326 \\
\hline Fetal wastage & 0 & 0 & \\
\hline
\end{tabular}

\section{DISCUSSION}

Labour is a physiological process and it brings a great joy and happiness to majority of families. The aim of successful labour management is to ensure the safe delivery of healthy baby to a healthy mother.

The age group in the present study is 19-30 years which is comparable with study of Mikki et al, Abdullah A et al. ${ }^{4,5}$ In other studies as Blanch et al, Sadler et al the mean age was considered. ${ }^{6,7}$ In a study by Sadler LC et al duration of first stage of labour is 290 (145-460) $\mathrm{min}$ in control group and 240 (120-390) min in study group which is comparable to the present study. ${ }^{7}$

When mode of delivery was observed it was seen that almost $78 \%$ of patients of control group and $88 \%$ of study group had vaginal delivery; $18 \%$ patients in control group and $10 \%$ in study group had instrumental delivery. The caesarean section was performed in $4 \%$ of patients in control group while $2 \%$ in study group, therefore, it is seen that there is no significant difference statistically. This matches with the result of Abdullah A et al. ${ }^{5}$

Duration and amount of blood loss is less in study group which is comparable to the study done by Sulochana. ${ }^{12}$ Most of the authors has not observed any significant difference in the APGAR score. APGAR of the babies at 5 min showed that the oxytocin used had no adverse effects on the fetus.

In a study Akoury et al, there were no significant differences were detected in the occurrence of fetal complications between the control and study groups, which is comparable to the present study. 59 In a study by Sadler LC et al, there were no differences in maternal infectious morbidity or postpartum haemorrhage which is comparable to the present study. ${ }^{7}$

50 randomized controlled trials have found no difference in caesarean section rates, rate of operative vaginal delivery or neonatal outcome. It again supports our results with regards to operative delivery and neonatal outcome. Artificial rupture of membranes (amniotomy) to shorten labour has been widely practiced by obstetricians, 
but some opponents have argued that it increases the risk of infection, cord prolapsed, abruption placenta, which in turn increases maternal and perinatal morbidity and mortality. ${ }^{13}$ In the developed countries many trials do not recommend amniotomy to accelerate labour but in developing countries like ours the practice of amniotomy seems to be justified.

Table 6: Comparison of duration of stages of labour.

\begin{tabular}{|lll|}
\hline Authors & $\begin{array}{l}\text { Stage of labour in minutes } \\
\text { Control group }\end{array}$ & Study group \\
\hline Duration of $\mathbf{1}^{\text {st }}$ stage of labour in minutes & & \\
\hline Garite $^{8}$ & $457 \pm 233(\mathrm{n}=224)$ & $347 \pm 206(\mathrm{n}=235)$ \\
\hline Guerresi $^{9}$ & $209 \pm 141(\mathrm{n}=50)$ & $212 \pm 97(\mathrm{n}=50)$ \\
\hline Serman $\mathrm{F}^{10}$ & $405 \pm 45(\mathrm{n}=40)$ & $250 \pm 50(\mathrm{n}=50)$ \\
\hline Sadler LC $^{7}$ & $290(145-460)(\mathrm{n}-331)$ & $240(120-390)(\mathrm{n}=320)$ \\
\hline Present study & $351.4 \pm 139.72$ & $182 \pm 51.54$ \\
\hline Duration of $\mathbf{2}^{\text {nd }}$ stage of labour in minutes & & \\
\hline${\text { Vergani } \mathrm{P}^{11}}^{\text {Sadler LC et al }}{ }^{7}$ & $69.09 \pm 37.02(\mathrm{n}=16)$ & $59.63 \pm 27.53(\mathrm{n}=16)$ \\
\hline Present study $^{\text {rd }}$ stage blood loss & $60 \pm 35-100(\mathrm{n}=331)$ & $59 \pm 33-106(\mathrm{n}=320)$ \\
\hline Sulochana & & $34.95 \pm 12.98$ \\
\hline Present Study & $68.8 \pm 26.14$ & $100-150$ \\
\hline & $150-250$ & $90-195$ \\
\hline
\end{tabular}

In government hospitals there are many patients in the labour room with few doctors, nurses and midwives. This creates difficulty for paramedics to do proper monitoring of every patient for elongated period. In these circumstances, amniotomy serves many advantages e.g. It accelerates labour thus decreasing overall monitoring time. Also the colour of liquor gives idea about the foetal wellbeing, which helps in deciding the mode of delivery and making preparation for neonatal resuscitation.

The latent phase commences with maternal perception of regular contraction and in the presence of progressive, slow cervical dilatation ends at between $3-4 \mathrm{~cm}$ of dilatation which is the threshold for the active phase transition. At this point only active management of labour is to be started so that false labour cases can be excluded. Evidence presented in Blanch showed a statistically significant improvement in maternal satisfaction in those women randomised to amniotomy. ${ }^{6}$ Sulochana et al, was able to reduce this incidence of postpartum haemorrhage to $6 \%$ in cases electively induced with oxytocin drips by continuing the drip for 2-4 hours after delivery and reasons for the figure in our series being low may be due to continuing the drip for a few hours after delivery. ${ }^{12}$

\section{CONCLUSION}

In present study mean duration of $1^{\text {st }}$ stage of labour is reduced in the study group with difference of 169 minutes. Mean duration of $2^{\text {nd }}$ stage of labour is reduced in the study group with difference of 3-4 minutes. The mean total duration of labour is reduced in study group with a difference of 204 minutes. Quantity and duration of blood loss is significantly less in study group when compared to control group. There was no significant difference in terms of mode of delivery, maternal and foetal outcome between the two groups. So, oxytocin infusion combined with amniotomy is safe and effective in accelerating the first and second stage of labour in apparently normal cases. No statistically significant adverse effects were noted with oxytocin infusion and amniotomy.

Funding: No funding sources

Conflict of interest: None declared

Ethical approval: The study was approved by the Institutional Ethics Committee

\section{REFERENCES}

1. Klasko SK, Cummings RV, Balducci J, DeFulvio JD, Reed JF. $3^{\text {rd }}$ The impact of mandated in-hospital coverage on primary cesarean delivery rates in a large non-university teaching hospital. Am J Obstet Gynecol. 1995;172(2 Pt 1):637-42.

2. Spetz J, Smith MW, Ennis SF. Physician incentives and the timing of cesarean sections: evidence from California. Med Care. 2001;39(6):536-50.

3. Barber EL, Lundsberg LS, Belanger K, Pettker CM, Funai EF, Illuzzi JL. Indications contributing to the increasing cesarean delivery rate. Obstet Gynecol. 2011;118(1):29-38. 
4. Mikki, Wick N, Abu-Asab L, Abu-Rmeileh N, Niveen. A trial of amniotomy in a Palestinian hospital. J Obstet Gynaecol. 2007;27:368-73.

5. Abdullah A, Saboohi S, Hashami U. Effects of amniotomy versus spontaneous rupture of membrane on progress of labour and foetal outcome in primigravidae. J Liaq Uni Med Health Sci. 2010;9(1):33-6.

6. Blanch G, Walkinshaw S, Alfirevic Z. Dysfunctional labour: a randomised trial. $\mathrm{Br} \mathrm{J}$ Obst Gynaecol. 1998;105:117-20.

7. Sadler LC, Davison T, McCowan LME. Maternal satisfaction with active management of labor: a randomized controlled trial. Birth. 2001;28:225-35.

8. Clark SL, Simpson KR, Knox GE, Garite TJ. Oxytocin: new perspectives on an old drug. Am J Obstet Gynecol. 2009;200:35e1-6.

9. Gagnon-Gervais K, Iglesias MH, Duperron L, Masse A, Mayrand MH, Sansregret A, et al. Early vs late amniotomy for labor induction: a randomized controlled trial. Am J Obst Gynecol. 2011;204(1 Suppl):S127.

10. Serman F, Benavides C, Sandoval J, Pazols R, Bernedo J, Fuenzalida R, et al. Active labour management in primiparas. Prospective study. Int $\mathbf{J}$ Obst Anesth. 1995;60(1):6-11.

11. Vergani P, Ornaghi S, Pozzi I, Beretta P, Russo FM, Follesa I, Ghidini A. Placenta previa: distance to internal os and mode of delivery. Am J Obstet Gynecol. 2009;201(3):266.e1-266.e5.

12. Tuddenham SA, Rahman MH, Singh S, Barman D, Kanjilal B. Care seeking for postpartum morbidities in Murshidabad, rural India. Int J Gynaecol Obstet. 2010;109:245-6.

13. Dhakal S, Chapman GN, Simkhada PP, van Teijlingen ER, Stephens J, Raja AE. Utilisation of postnatal care among rural women in Nepal. BMC Pregnancy Childbirth. 2007;7:19.

Cite this article as: Jyothi $\mathrm{K}$, Shakunthala $\mathrm{S}$.

Compare the effect of amniotomy and oxytocin infusion in duration of labour. Int $\mathrm{J}$ Reprod Contracept Obstet Gynecol 2019;8:3123-8. 